\title{
ОКРЕМІ ПИТАННЯ ПРОТИДІї ТРАНСНАЦІОНАЛЬНІЙ ЗЛОЧИННОСТІ ЯК ЗАГРОЗІ СВІТОВІЙ ЕКОНОМІЦІ В УМОВАХ ГЛОБАЛІЗАЦІї
}

Шкурко В. I.

\begin{abstract}
здійснено аналіз нормативного закріплення поняття транснаціональної злочинності та видів злочинних посягань, що ним охоплюються. Досліджено проблеми впливу транснаціональної організованої злочинності на світову економіку в контексті глобалізації. Акцентовано увагу на питаннях зростання тіньової економіки та використання офшорних зон для забезпечення функціонування транснаціональних організованих угрупувань. Окреслено базові шляхи протидії розвитку та поширенню організованої транснаціональної злочинності.
\end{abstract}

Ключові слова: транснаціональна злочинність, глобалізація, інтеграція, світова економіка.

Осуществлен анализ нормативного закрепления понятия транснациональной преступности и видов преступных посягательств, которые им охватываются. Исследовань проблемы влияния транснациональной организованной преступности на мировую экономику в контексте глобализации. Акцентировано внимание на вопросах роста теневой экономики и использования оффшорных зон для обеспечения функционирования транснациональных организованных группировок. Определены базовые пути противодействия развитию и распространению организованной транснациональной преступности.

Ключевые слова: транснациональная преступность, глобализация, интеграция, мировая экономика.

It is established that modern intensive processes of world integration are positively reflected in the overwhelming majority of socio-political and economic phenomena. Facilitating progress, establishing corporate interconnections between countries of the world, increasing the mobility of capital, goods, services and ideas, globalization leads to the emergence of some negative results, which include transnational crime.

It has been found out that in both domestic and foreign scientific literature general approaches to the development of a conceptual apparatus of transnational organized crime, its characteristics, general tendencies and prospects of development are not outlined.

In this case, conceptually under the concept of a transnational crime is understood different types of criminal offenses that are classified as organized crime, corporate, professional and political crimes, etc.

Scientific literature notes that at the beginning of the 21 st century transnational crime reached unprecedented levels and poses a real threat to the security of the world economy.

The development of transnational organized crime is connected, first of all, with global processes in the global economy the movement of a large mass of capital. The above became possible due to the liberalization of financial markets and transactions, the rapid development of infrastructure associated with new information technologies, the use of unknown financial instruments to date.

The mentioned tendencies of integration of the world economy have caused the emergence of a world system of "shadow"

Шкурко В. І., 2019 economies that are not taxed in offshore areas, and which is the basis, the foundation for the success of transnational organized criminal groups. The factors that influence the degree of control of the shadow economy by transnational organized criminal groups are noted.

Among the reasons for the consolidation of these entities is highlighted: the growth of the so-called professionalism of criminals, the use of the advantages of international trade in the conditions of globalization, corporatization, rational reorganization of the criminal world by analogy with legitimate entrepreneurial activity in legal markets. Due to the strict hierarchy, the actual isolation of the leaders of transnational criminal organizations from the executive branch takes place, which causes significant difficulties in establishing and detecting their direct participation in specific types of criminal activity. With flexibility and mobility, transnational criminal organizations demonstrate extreme mobility and the ability to respond quickly to measures taken by law enforcement agencies.

The conclusions state that transnational crime is considered one of the most threatening factors that destroys the global economy, leads to the poverty of the population of the countries concerned and provokes an increase in crime in general.

Key words: transnational crime, globalization, integration, world economy.

Постановка проблеми та їі актуальність. Сучасні інтенсивні процеси світової інтеграції позитивно відбиваються у більшості соціально-політичних й економічних явищ на всіх рівнях: внутрішньодержавному, регіональному, планетарному. Сприяючи прогресу, налагодженню корпоративних взаємозв'язків між країнами світу, підвищенню мобільності капіталів, товарів, послуг та ідей, глобалізація зумовлює появу деяких негативних результатів. Наприклад, під їі впливом змінюється багато соціальних девіацій, зокрема злочинність, відбувається іï інтернаціоналізація й транснаціоналізація. Прагнучи отримувати надприбутки, кримінальні структури виходять на світові ринки, займають окремі їх сегменти, закріплюються у системі міжнародних економічних зв'язків, розширюючи географію вчинення транскордонних злочинів.

У науковій літературі справедливо підкреслено, що сучасна злочинність стала більш мобільною і діяльною. Вказаному сприяє посилення міграційних процесів, лібералізація режиму перетину державних кордонів, використання правопорушниками новітніх інформаційних, телекомунікаційних, транспортних, банківських та інших технологій, що дають змогу посягати на охоронювані законом об' єкти «дистанційно» (перебуваючи за межами держави, на території якого заподіюється злочинна шкода) [1, с. 13]. Зростаюча кількість організованих транснаціональних злочинних об'єднань, зокрема у сфері економіки, стає сьогодні суттєвим фактором посилення соціальної напруги і дестабілізації суспільних відносин, перешкоджає оздоровленню економіч- 


\section{Економічна безпека держави: теорія і практика}

них систем, впорядкуванню споживчого ринку, сприяє деформації нових форм економічних підприємницьких відносин, збільшенню частки «тіньової» та «офшорної» економіки тощо [2, с. 167; 3, с. 259]. Тому обізнаність щодо сфер впливу транснаціональної злочинності, ступеня їх розвиненості та усвідомлення реальних масштабів потенційної шкоди від їх діяльності мають велике значення для посилення інтенсивності пошуку шляхів перешкоджання та запобігання організованій злочинності та їі негативних наслідків, зокрема для соціального-економічного середовища України.

Аналіз останніх досліджень і публікацій. У науковій літературі дослідженню питання транснаціональної злочинності та вивченню окремих її проявів приділило увагу чимало таких науковців, як: М.Г. Вербенський, В.О. Глушков, В.В. Голіна, О.М. Джужа, О.Ф. Долженков, В.М. Дрьомін, Г.П. Жаровська, А.П. Закалюк, С.Ф. Здоровко, Н.А. Зелінська, О.В. Козаченко, В.П. Корж, І.В. Крикунової (Шадрової), Г.П. Пожидаєва, В.С. Полянська, І.В. Пшеничний, Е.В. Расюк, В.І. Сідоров, Є.Д. Скулиш, Є.Л. Стрельцов, М.І. Хавронюк та інші. Незважаючи на наявні дослідження впливу транснаціональної злочинності на міжнародну економіку, окремої деталізації та аналізу потребують конкретні прояви цієї форми організованої злочинності з урахуванням невпинних загальносвітових інтеграційних процесів.

Метою статті $€$ визначення особливостей транснаціональної злочинності, дослідження питань, пов'язаних із практичними проявами цього негативного явища та міжнародним засобам його протидії в контексті глобалізації світової економіки.

Виклад основного матеріалу. Як справедливо зауважують окремі науковці (криміналісти, міжнародники), транснаціональна злочинність $€$ досить складним явищем як об'єкт дослідження і вимагає значних зусиль для аналізу. У зв'язку з цим як у вітчизняній, так і зарубіжній науковій літературі не окреслено загальноприйняті підходи щодо вироблення понятійного апарату транснаціональної організованої злочинності, їі характеристик, загальних тенденцій і перспектив розвитку [4, с. 444; 2, с. 168]. При цьому концептуально під поняттям транснаціонального злочину розуміють різні види кримінальних правопорушень, що віднесені до категорій вчинюваних організованою злочинністю, корпоративних, професійних і політичних злочинів тощо [5, с. 34].

Ще у 20-ті рр. минулого століття частина юристів звертала увагу на перші прояви організованої злочинності, що мають транснаціональні зв'язки, однак лише у 70-ті рр. XX ст. указаний феномен привернув увагу громадськості та наукової спільноти, у зв'язку з публікаціями у ЗМІ гучних розслідувань щодо наркотрафіків та торгівлі зброєю.

Досі немає також нормативного визначення транснаціональної злочинності. Перше своє уніфіковане бачення щодо цього явища світове товариство запропонувало у 1988 році на Міжнародному симпозіумі з організованої злочинності в Санкт-Клауде. У результаті обговорення було взято за основу робочу формулу, відповідно до якої транснаціональна злочинність розуміється як будь-яка постійна участь групи людей або організації у злочинній діяльності, головна мета якої - отримання прибутку всюди, незважаючи на наявність державних кордонів [2, с. 168].
Відповідно до ч. 2 ст. 3 Конвенції ООН проти транснаціональної організованої злочинності від 15.11.2000 р. (далі - Конвенція; ратифікована Україною 04.02.2004р.), злочин має транснаціональний характер за таких умов:

а) він учинений у більше ніж одній державі;

b) він учинений в одній державі, але істотна частина його підготовки, планування, керівництва або контролю має місце в іншій державі;

с) він учинений в одній державі, але за участю організованої злочинної групи, яка здійснює злочинну діяльність у більше, ніж одній державі;

d) він учинений в одній державі, але його істотні наслідки мають місце в іншій державі [6].

Керуючись загаданими положеннями та матеріалами Всесвітньої конференції про організовану злочинність (М. Неаполь, Італія, 21-23 листопада 1994 року) М.Г. Вербенський визначає транснаціональну злочинність як системне функціонування злочинних організацій і співтовариств, що мають розгалужену мережу філій в інших країнах, які використовують міжнародні зв'язки для постійного здійснення глобальних незаконних операцій, пов'язаних з переміщенням потоків інформації, грошей, фізичних об'єктів, людей, інших матеріальних і нематеріальних ресурсів через державні кордони з метою використання сприятливої ринкової кон'юнктури в одній або кількох іноземних державах для одержання істотної економічної вигоди, а також для ефективного ухилення від соціального контролю за допомогою корупції, насильства й використання протиріч і прогалин у системах кримінального законодавства та правосуддя різних країн [7, с. 11].

Втім, до найбільш поширених форм транснаціональної організованої злочинності належать протиправні посягання не тільки у сфері економіки, а й у сфері незаконного обороту наркотичних засобів, терористична діяльність, піратство тощо.

Є.Д. Скулиш та В.О. Глушков визначають транснаціональну організовану злочинність як якісно нову форму розвитку національної організованої злочинності, один із вищих рівнів кримінальної еволюції, суб'єктами якої $\epsilon$ стійкі злочинні організації, сфера впливу та діяльність яких у вигляді злочинного промислу поширюється на декілька держав, групу сумісних держав, регіон, континент або світове співтовариство [8, с. 193].

Конвенція від 15.11.2000 р. також не надає визначення поняттю «транснаціональна організовані злочинність». При цьому вона містить приблизний перелік злочинів, що підпадають під це визначення, а саме:

1) участь в організованій злочинній групі (ст. 5 Конвенціі);

2) відмивання доходів від злочинів (ст. 6 Конвенції);

3) корупція (ст. 8 Конвенції);

4) перешкоджання здійсненню правосуддя (ст. 23 Конвенції) [6].

Перелік цих протиправних діянь не $\epsilon$ вичерпним, оскільки розвиток і ускладнення суспільних відносин веде як до ускладнення і урізноманітнення форм і методів вчинення правопорушень, так і до появи, відповідно, нових їх видів.

Загалом, на підставі аналізу керівних документів ООН В.І. Сідоров та С.Ф. Здоровко відокремлюють 17 груп транснаціональних злочинів: 1) відмивання брудних грошей; 2) тероризм; 3) крадіжки творів 
мистецтва та предлметів культури; 4) крадіжки інтелектуальної власності; 5) незаконна торгівля зброєю; 6) викрадення літаків; 7) морське піратство; 8) захоплення наземного транлспорту; 9) шахрайство з наземним транспортом; 10) комп'ютерні злочини; 11) екологічні злочини; 12) торгівля людьми; 13) торгівля людськими органами; 14) незаконна торгівля наркотиками; 15) фальшиве банкрутство; 16) проникнення в легальний бізнес; 17) корупція й підкуп громадських і партійних діячів, виборних осіб [3, с. 267].

При цьому у кожному окремо взятому регіоні світу можливо виокремити й інші, притаманні лише йому суспільно небезпечні посягання, які вчинюються учасниками транснаціональних злочинних угруповань.

Так, на жаль, останніми роками в Україні великих масштабів набули виготовлення та контрабанда алкогольних і тютюнових виробів, а також фальсифікація лікарських засобів [9, с. 286-287].

У науковій літературі відмічають, що на початку XXI століття транснаціональна злочинність досягла безпрецедентних масштабів і становить реальну загрозу безпеці світової економіки [10, с. $171 ; 11$, с. 36]. Через це констатовано, що транснаціональна організована злочинність у XXI столітті не тільки не була подолана, а й набула нового виміру - з'явилися нові їі види. Слід указати, що деякі держави почали використовувати найсучасніший досвід транснаціональних злочинів для діяльності проти інших країн, зокрема, йдеться про такі злочини, як кібертероризм [12, с. 245].

Найбільш впливовими та потужними транснаціональними організованими угрупованнями у світі за твердженням окремих дослідників $\epsilon$ : «La Cosa Nostra» у США, «Cosa Nostra» в Європі (Італія), в Азї - «Triada» (Китай) i «Yakuza» (Японія), а також колумбійські наркокартелі Латинської Америки, ямайсько-британська, албанська, сербська, ізраїльська, мексиканська мафії [13, с. $155 ; 3$, с. 260-263].

Розвиток транснаціональної організованої злочинності пов'язаний, насамперед, з глобальними процесами у світовій економіці - руху великої маси капіталів. Указане стало можливим внаслідок лібералізації фінансових ринків та трансакцій, бурхливого розвитку інфраструктури, пов'язаної з новими інформаційними технологіями, використання до цього часу невідомих фінансових інструментів (ф'ючерси, опціони та т. п.) [14, с. 59].

Названі тенденції інтеграції світової економіки спричинили виникнення світової системи «тіньової» економіки, яка не обкладається податками в офшорних зонах, і яка $є$ базисом, фундаментом для успішної діяльності транснаціональних організованих злочинних груп. На думку окремих дослідників, без «тіньової» світової економіки транснаціональної організованої злочинності не було б узагалі [3, с. 256].

В узагальненому вигляді тіньова економіка характеризується двома складовими: 1) діяльність з виробництва та реалізації товарів і послуг, обіг яких не заборонено законом, але здійснюється поза контролем держави й не тягне кримінальну відповідальність; 2) діяльність, яка прямо заборонена законом про кримінальну відповідальність.

Якщо перший вид (так звана «сіра економіка») позбавляє державу податкових надходжень, що призводить до невиконання бюджету країни, то другий - заподіює шкоду здоров'ю людей, моральності суспільства, безпеці держави (торгівля людьми та людськими органами, проституція, незаконні дії з наркотиками, підробка лікарських засобів, торгівля зброєю, несанкціоновані викиди шкідливих відходів у довкілля тощо) [14, с. 63].

Контроль тіньової економіки з боку транснаціональних організованих злочинних груп став можливий завдяки:

отриманню реальної можливості опосередковано вплилвати на політику держави або самим долучатися до управління державою чи їі окремими інститутами;

використанню найсучасніших інформаційних технологій, засобів транспорту та комунікації;

тотальний контроль над певною сферою кримінальної діяльності (наприклад, контроль над найбільш прибутковими державними підприємствами, окремими галузями, цілими промисловими регіонами);

підкуп як національних, так і іноземних посадових осіб з метою отримання можливості вести або продовжувати економічну діяльність у якій-небудь країні або отримувати які-небудь преференції (корупція) [2, с. 169-170].

Внаслідок зрощування кримінального бізнесу з банками, останні становляться частиною кримінального бізнесу, а точніше його «фасадом». Зацікавленість банків у незаконних коштах (наркотики, зброя, торгівля людьми тощо) очевидна, оскільки вони «брудні», то банки отримують їх з «дисконтом» (за надання «послуг» та за «ризики»). Інвестиційні фонди також можуть також співпрацювати з криміналом, інвестуючи їх кошти в цінні папери на фондовому ринку [14, с. 63].

Майже половина світових фінансових угод припадає на офшорні території (Сейшельські острови, Британські Віргінські острови, Ліхтенштейн, деякі кантони Швейцарії, штати США - Делавер, Вайомінг). Відсутність оподаткування або надзвичайно низькі ставки податків щодо результатів фінансової чи іншої діяльності, відмова від надання інформації про чинний режим оподаткування, наявність корпоративного законодавства, яке дозволяє утворювати компанії під контролем іноземців, притягують не тільки транснаціональні корпорації, але й транснаціональну злочинність.

Зростанням так званого професіоналізму злочинців, використанням ними переваг міжнародної торгівлі в умовах глобалізації, корпоратизація, раціональна реорганізація злочинного світу за аналогією із законною підприємницькою діяльністю на легальних ринках свідчить про тенденції ускладнення мережевих зв'язків та організаційної структури злочинних угруповань. Внаслідок суворої ієрархічності відбувається фактична ізоляція ватажків транснаціональних злочинних організацій від виконавської ланки, що спричиняє суттєві труднощі у встановленні та виявленні їх безпосередньої участі у конкретних видах злочинної діяльності [15, с. 14]. Демонструючи гнучкість і мобільність, транснаціональні злочинні організації демонструють надзвичайну рухомість і здатність швидко реагувати на заходи, що вживаються правоохоронними органами.

Окрім впливу на економічні зв'язки, транснаціональна злочинність як глобальна соціально-економічна та політична інституціональна система, на думку Г.П. Жаровської, може на власний розсуд керувати державою, визначати долю громадян, а також перетворювати цілі регіони на анклави, в яких не діють закони, а правоохоронці фактично (за рідким виключенням) 


\section{Економічна безпека держави: теорія і практика}

сприяють мілітаризації транснаціональних злочинних організацій [16, с. 35].

$\epsilon$ позиція, згідно з якою поява транснаціональних злочинних організацій $\epsilon$ також наслідком глобальних змін, що відбулися на економіко-політичній мапі світу: розпад СРСР та утворення ряду самостійних, але економічно дуже слабких та незахищених держав з прозорими кордонами, які фактично не охороняються; утворення Європейського Союзу, що призвело до послаблення митних процедур, паспортного та валютного контролю в Європі; зміни в політиці Китаю, які надали поштовх для активного зростання економічних відносин в цій країні; укладання Північноамериканської угоди про вільну торгівлю тощо [17].

Отже, за наявності позитивних тенденцій глобалізація вимушено поставила перед міжнародною спільнотою складне завдання: відшукати шляхи та дієві механізми для припинення процесу розповзання транснаціональної злочинності в масштабах нашої планети в умовах відкритості кордонів між країнами пов'язаної з процесами інтеграції світової економіки.

У науковій юридичній літературі виокремлюють такі базові організаційно-правові форми міжнародного співробітництва у боротьбі з транснаціональною злочинністю та їі організованих форм, як:

1) вжиття заздалегідь узгоджених заходів по встановленню на міжнародно-правовому рівні злочинності та караності певних суспільно небезпечних дій (договірна криміналізація міжнародних злочинів та злочинів міжнародного характеру);

2) розроблення та укладання міжнародних угод, прийняття інших міжнародно-правових документів в якості правової основи діяльності держав, міжнародних організацій та їх органів у сфері боротьби зі злочинністю;

3) видання документів, які регламентують порядок здійснення повноважень держав в межах укладених міжнародних угод, процесуальний порядок здійснення міжнародного правосуддя, а також співпраці держав у боротьбі зі злочинністю;

4) утворення та формування на договірній та іншій міжнародно-правовій основі міжнародних організацій та інших органів, які здійснюють свою діяльність у сфері боротьби зі злочинністю;

5) взаємодія щодо запобігання тим, що готуються, або вчиненим злочинам, зокрема, шляхом проведення за необхідності оперативно-розшукових заходів (спеціальних розслідувань щодо термінології міжнародних угод);

6) надання взаємної правової допомоги у сфері кримінального судочинства (видача, здійснення кримінального переслідування по запитах іноземних держав або передача юрисдикції, співпраця з органами міжнародної кримінальної юстиції);

7) діяльність міжнародних організацій та органів (органів міжнародної кримінальної юстиції) по відправленню правосуддя за вчинені транснаціональні злочини, здійснення кримінального переслідування винних [14, с. 66].

На думку О.І. Плужнік, протидія розвитку та поширення організованої транснаціональної злочинності потребує розроблення та впровадження в дію ефективного механізму боротьби з цим явищем, визначення причин її виникнення, яке охоплює усі сфери суспільного життя, з урахуванням таких факторів, а саме: це злочини, які вчинюються на території однієї країни громадянами іншої країни з використанням їі можливостей;

діяльність поширюється на територію двох чи більше держав;

члени організованої групи є громадянами двох чи

більше держав;

приготування, планування та координація злочинів відбуваються з території іншої держави;

високий ступінь небезпеки злочину для більш, ніж однієї держави.

Отже, для належного розвитку суспільства та держави в цілому, головним фактором виступає гарантування ії безпеки та цілісності від протиправних посягань з боку транснаціональних злочинних угруповань [18, с. 49].

Висновки. Транснаціональна злочинність вважається одним із найбільш загрозливих факторів, що руйнує світову економіку, призводить до бідності населення відповідних країн і провокує зростання злочинності в цілому. Треба констатувати, що світова спільноті досі не виробила дієвих механізмів протидії та стратегій боротьби із цим явищем. Відтак, дослідження останніх повинні бути продовжені на більш глибинному рівні, оскільки їх актуальність лише зростає. Подальші дослідження мають бути спрямовані не тільки на вдосконалення міжнародно-правового регулювання питань протидії транснаціональній злочинності, а й на можливості для нашої держави зробити свій вагомий внесок у це питання, поліпшивши роботу власних правоохоронних структур.

\section{Література}

1. Житний О.О. Міжнародне «антикримінальне» співробітництво України та протидія злочинності. Вісник кримінологічної асоціації України. 2014. № 8. С. 13-23.

2. Полянська В.С. Транснаціональна організована злочинність у сфері економіки: сутність та ознаки. Південноукраїнський правничий часопис. 2016. № 2. С. 167-170.

3. Сідоров В.І., Здоровко С.Ф. Вплив глобальної економіки на транснаціональну організовану злочинність. Проблеми законності. 2017. № 136. С. 250-271.

4. Скулиш Є.Д. Транснаціональна організована злочинність: проблема визначення та основні ознаки. Держава і право. Серія: Юридичні і політичні науки. 2005. Вип. 30. С. 444-451.

5. Зелінська Н.А., Дрьомін В.М. Кримінальна глобалізація: від транснаціонального злочину до транснаціональної злочинності. Юридичний вісник. 2011. № 1. С. 34-39.

6. Конвенція Організації Об'єднаних Націй проти транснаціональної організованої злочинності від 15.11.2000 (ратифікована Україною 04.02.2004). Офіційний сайт Верховної Ради України. URL: http://zakon.rada.gov.ua/laws/ show/995_789 (дата звернення: 16.03.2019).

7. Вербенський М.Г. Транснаціональна злочинність: кримінологічна характеристика та шляхи запобігання : автореф. дис. ... д-ра юрид. наук : 12.00.08. Дніпропетровськ. 2010. 40 с.

8. Скулиш Є.Д., Глушков В.О. Поняття транснаціональної організованої злочинності та її співвідношення 3 тероризмом. Право і суспільство. 2012. № 2. С. 190-194.

9. Пивоваров В.В., Литвин А.Д. Міжнародна спеціалізація транснаціональної злочинності в Україні. Порівняльно-аналітичне право. 2018. № 1. С. 285-288.

10. Крикунова (Шадрова) І.В. Транснаціональна економічна злочинність в умовах криміналізації глобалізаційних процесів. Молодий вчений. 2014. № 12 (1). С. 165-171. 
11. Івашина О.Ф., Матвійчук І.О. Субстанціональні глобальні виклики розвитку світової економіки та їх вплив на економічну безпеку держави. Бізнесінформ. 2013. № 8. C. 34-38.

12. Тацієнко В.В. Актуальність дослідження питань протидії транснаціональній економічній злочинності. Підприємництво, господарство і право. 2018. № 12. C. 244-248.

13. Бусол О.Ю. Транснаціональні злочинні угруповання та транснаціональні корпорації: межі корупційного симбіозу. Вчені записки ТНУ ім. В.І. Вернадського. Серія: Юридичні науки. 2018. Т. 29 (68). Вип. 4. С. 154-159.

14. Сідоров В.І., Здоровко С.Ф. Глобалізація економіки та транснаціональна організована злочинність. Вісник ХНУ ім. В.Н. Каразіна. Серія: Міжнародні відносини. Економіка. Країнознавство. Туризм. 2017. Вип. 6. С. 58-70.

15. Вербенський М.Г., Расюк Е.В. Ознаки сучасних транснаціональних злочинних організацій та транснаціонального наркобізнесу. Науковий вісник Дніпропетров- ського державного університету внутрішніх справ : зб. наук. праць. 2007. № 3. С. 1-23.

16. Жаровська Г.П. Транснаціональна злочинність як загроза національній безпеці України. Науковий вісник Ужгородського національного університету. Серія: Право. 2014. Вип. 27. Т. 3. С. 33-37.

17. Репецкая А.Л. Тезисы к докладу. Материалы круглого стола: «Глобализация общей, организованной и коррупционной преступности». Москва. 2001. С. 45-50.

18. Плужнік О.І. Поняття та особливості організованої транснаціональної злочинності. Південноукраїнський правничий часопис. 2016. № 2. С. 47-49.

Шкурко В. І., аспірант кафедри права Європейського Союзу Національного юридичного університету імені Ярослава Мудрого ORCID 0000-0002-0236-3310 